\title{
The Association of Acute Kidney Injury With Disease Severity and Mortality in COVID-19: A Systematic Review and Meta-Analysis
}

Trishala Menon ${ }^{1}$, Rohit Sharma ${ }^{2}$, Saurabh Kataria ${ }^{3,4}$, Sundus Sardar ${ }^{2}$, Ramesh Adhikari 5, 6 , Sohaib Tousif $^{7}$, Hira Khan ${ }^{8}$, Sawai Singh Rathore ${ }^{9}$, Romil Singh ${ }^{10}$, Zahoor Ahmed ${ }^{11}$

1. Family Medicine, Wheeling Hospital, Wheeling, USA 2. Internal Medicine, Hamad Medical Corporation, Doha, QAT 3. Neurology and Neurocritical Care, University of Missouri Health Care, Columbia, USA 4. Neurology, West Virginia University, Morgantown, USA 5. Hospital Medicine, Franciscan Health, Lafayette, USA 6. Geriatrics, Brown University, Providence, USA 7. Medicine, Ziauddin University, Karachi, PAK 8. Internal Medicine, Islamic International Medical College, Rawalpindi, PAK 9. Internal Medicine, Dr. Sampurnanand Medical College, Jodhpur, IND 10. Critical Care, Mayo Clinic, Rochester, USA 11. Internal Medicine, King Edward Medical University, Mayo Hospital, Lahore, PAK

Corresponding author: Romil Singh, singh.romil20@gmail.com

\section{Abstract}

\section{Background and objective}

The coronavirus disease 2019 (COVID-19) pandemic has become a global healthcare emergency. The severe acute respiratory syndrome coronavirus 2 (SARS-CoV-2), the causative agent of COVID-19, has a wide range of clinical manifestations ranging from subclinical infection to multi-organ failure. In addition to the respiratory system, COVID-19 also adversely affects the kidneys. In this study, we aimed to measure the prevalence of acute kidney injury (AKI) in COVID-19 and its association with the disease severity and mortality in COVID-19 patients.

\section{Materials and methods}

We conducted our study by following the Preferred Reporting Items for Systematic Review and Metaanalyses (PRISMA) guidelines. A comprehensive literature search using four databases (PubMed, EMBASE, Google Scholar, and clinicaltrial.gov) was performed. Our initial search returned 2,771 articles. After excluding review articles, duplicates, and non-relevant studies, we included 20 articles that reported an association between COVID-19 and AKI. We subsequently performed a random effect analysis to find the pooled prevalence, pooled odds ratio (OR) estimates, and 95\% confidence intervals for severe COVID-19 and mortality outcomes in AKI using Cochrane RevMan (version 5.4) and R programming language (version 4.16-2).

\section{Results}

A total of 14,415 patients from various countries were included. Among the 20 cohorts, the median age was $55.8 \pm 8.39$ years (range: $43-72$ years), and $43.78 \%$ of the subjects were female. Out of a total of 14,415 patients, 3,820 developed AKI with a pooled prevalence of $11 \%$ (95\% CI: 0.07-0.15; $\mathrm{p}<0.01 ; \mathrm{I}^{2}=98 \%$ ). AKI was found to have a significant association with severe COVID-19 disease, with a pooled OR of 8.45 (95\% CI:

5.56-12.56; $\left.\mathrm{p}<0.00001 ; \mathrm{I}^{2}=0 \%\right)$. AKI was associated with significantly higher mortality in patients with COVID-19 with an OR of 13.52 (95\% CI: 5.43-33.67; $\mathrm{p}<0.00001 ; \mathrm{I}^{2}=88 \%$ ).

\section{Conclusion}

AKI manifests as a common COVID-19 complication, and COVID-19 patients with AKI generally have poor outcomes in terms of disease severity and mortality.

Categories: Internal Medicine, Nephrology

Keywords: covid-19, sars-cov-2, acute kidney injury, acute renal failure

\section{Introduction}

The severe acute respiratory syndrome coronavirus 2 (SARS-CoV-2) is the causative agent of coronavirus disease 2019 (COVID-19). The World Health Organization declared a COVID-19 pandemic in December 2019. COVID-19 generally affects the respiratory system, and the patients predominantly manifest fever, myalgia, cough, dyspnea, and flu-like symptoms. The clinical course of the COVID-19 is highly variable, ranging from asymptomatic infection to respiratory failure, multi-organ dysfunction, and mortality. Apart from the respiratory system, COVID-19 is also associated with hazardous effects on other body systems $[1,2]$. 
Several studies have underlined that older patients and patients with comorbidities are more susceptible to COVID-19, its more serious complications, and progression to severe disease. Recent literature has revealed renal involvement in COVID-19 patients as well [3]. Organ dysfunction such as those involving lungs and kidneys are associated with a high mortality rate [4]. During the SARS-CoV and the Middle East Respiratory Syndrome coronavirus (MERS-CoV) epidemics, a close relationship between coronavirus infection and acute kidney injury (AKI) was observed [4]. A recent study by Chu et al. reported that $5-15 \%$ of coronavirus patients tend to develop AKI [5]. Viral entry and replication into the target cells induce systemic inflammatory responses leading to multi-organ dysfunction. AKI in these patients might be due to hypoxemia, dehydration, underlying disease, or adverse effects of administered drugs [6].

In clinical practice, COVID-19 has had a significant impact on nephrology. Our study aimed to evaluate the association of AKI with COVID-19 and the outcomes related to the disease severity and prognosis of SARSCoV-2 patients with AKI.

\section{Materials And Methods}

\section{Search strategy and study design}

By following the Preferred Reporting Items for Systematic Review and Meta-analyses (PRISMA) guidelines, we performed a comprehensive literature search using four databases (EMBASE, PubMed, Google Scholar, clinicaltrial.gov) (Figure 1). Our search stratagem relied on the use of the Medical Subject Headings (MeSH) term and keywords for "SARS-CoV-2" and "acute kidney injury" from the date of COVID-19's inception to November 2020. Our initial search returned 2,771 articles. We were left with 75 full-length studies after excluding case reports, animal studies, duplicates, review articles, and irrelevant studies. We finally included 20 articles that reported an association between COVID-19 and AKI after carefully applying the inclusion and exclusion criteria.
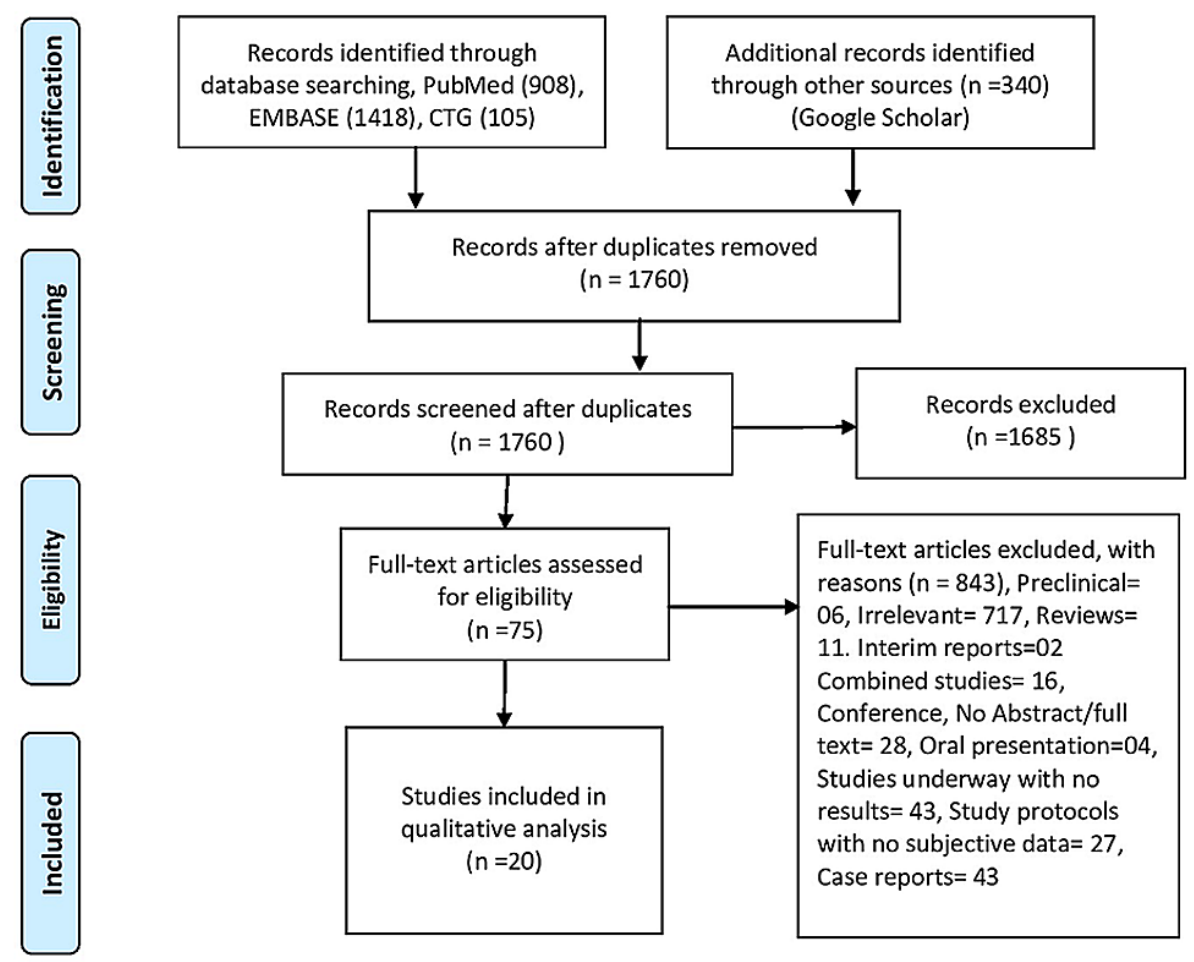

\section{FIGURE 1: PRISMA flow diagram}

PRISMA: Preferred Reporting Items for Systematic Review and Meta-analyses.

\section{Study characteristics and study selection}

We exported all studies to EndNote (version 8.0). We screened 669 studies, and 20 articles met our inclusion criteria. Initially, we screened articles by titles and abstract, assessing for relevance. Language restrictions were not imposed. Review articles were excluded. The studies with specialized populations such as cancer and pediatric patients and patients with chronic kidney disease (CKD) and end-stage renal disease (ESRD) were also excluded. We also excluded case reports and randomized clinical trials for drugs. In the beginning, we included full-length articles and then screened each cohort for inclusion criteria. We had prospective and retrospective studies reporting severe COVID-19 and AKI and studies with a more generalized population 


\section{Cureus}

and detailed extractable AKI-related data. Three authors screened all the articles and assessed full-length studies for inclusion and exclusion criteria. We resolved the disagreements through consensus.

\section{Data extraction and quality assessment}

We extracted the clinical information and relevant data using a standard Excel sheet. We reported age, gender ratio, publication year, and country where the study was conducted. We also tabulated outcomes, including AKI incidence (Table 1). In our study, the primary outcomes of interest were severe disease and death. We assessed the quality of studies using the Newcastle-Ottawa Scale (NOS) for quality assessment (Appendices). We also evaluated for the selection bias and small study effects using a random effect funnel plot model. 


\section{Cureus}

\begin{tabular}{|c|c|c|c|c|c|c|c|}
\hline Author & $\begin{array}{l}\text { Study } \\
\text { year }\end{array}$ & Location & Study type & $\begin{array}{l}\text { Total number of } \\
\text { patients }\end{array}$ & $\begin{array}{l}\text { Median age } \\
\text { (years) }\end{array}$ & $\begin{array}{l}\text { Male } \\
(\%)\end{array}$ & $\begin{array}{l}\text { AKI in COVID-19 } \\
\text { patients }\end{array}$ \\
\hline Cai et al. [7] & 2020 & China & $\begin{array}{l}\text { Retrospective, single- } \\
\text { center }\end{array}$ & 298 & 47 & 50 & 17 \\
\hline Cao et al. [8] & 2020 & China & $\begin{array}{l}\text { Retrospective, single- } \\
\text { center }\end{array}$ & 198 & 50.1 & 51 & 10 \\
\hline $\begin{array}{l}\text { Colaneri et } \\
\text { al. [9] }\end{array}$ & 2020 & Italy & $\begin{array}{l}\text { Retrospective, single- } \\
\text { center }\end{array}$ & 44 & 67.5 & 36.4 & 2 \\
\hline $\begin{array}{l}\text { Feng et al. } \\
\text { [10] }\end{array}$ & 2020 & China & $\begin{array}{l}\text { Prospective, single- } \\
\text { center }\end{array}$ & 114 & 64 & 62.39 & 35 \\
\hline Hu et al. [11] & 2020 & China & $\begin{array}{l}\text { Retrospective, single- } \\
\text { center }\end{array}$ & 323 & 61 & 51.5 & 17 \\
\hline $\begin{array}{l}\text { Huang et al. } \\
\text { [12] }\end{array}$ & 2020 & China & $\begin{array}{l}\text { Prospective, single- } \\
\text { center }\end{array}$ & 41 & 49 & 73 & 3 \\
\hline $\begin{array}{l}\text { Regina et al. } \\
\text { [13] }\end{array}$ & 2020 & Switzerland & $\begin{array}{l}\text { Observational, single } \\
\text { center }\end{array}$ & 200 & 70 & 60 & 30 \\
\hline $\begin{array}{l}\text { Wan et al. } \\
\text { [14] }\end{array}$ & 2020 & China & $\begin{array}{l}\text { Retrospective, single- } \\
\text { center }\end{array}$ & 135 & 47 & 53.3 & 5 \\
\hline Yan et al. [1] & 2020 & China & $\begin{array}{l}\text { Retrospective, } \\
\text { multicenter }\end{array}$ & 2,018 & 43 & 56 & 10 \\
\hline $\begin{array}{l}\text { Zhang et al. } \\
\text { [15] }\end{array}$ & 2020 & China & $\begin{array}{l}\text { Retrospective, single- } \\
\text { center }\end{array}$ & 221 & 55 & 48.9 & 10 \\
\hline $\begin{array}{l}\text { Zhao et al. } \\
\text { [16] }\end{array}$ & 2020 & China & $\begin{array}{l}\text { Retrospective, single- } \\
\text { center }\end{array}$ & 91 & 46 & 53.8 & 5 \\
\hline $\begin{array}{l}\text { Cao et al. } \\
{[17]}\end{array}$ & 2020 & China & $\begin{array}{l}\text { Retrospective, single- } \\
\text { center }\end{array}$ & 102 & 54 & 52 & 17 \\
\hline Brill et al. [18] & 2020 & UK & $\begin{array}{l}\text { Retrospective, single- } \\
\text { center }\end{array}$ & 450 & 72 & 60 & 80 \\
\hline $\begin{array}{l}\text { Chan et al. } \\
\text { [19] }\end{array}$ & 2020 & USA & $\begin{array}{l}\text { Observational, single- } \\
\text { center }\end{array}$ & 3,235 & 64 & 57 & 1,406 \\
\hline $\begin{array}{l}\text { Hirsch et al. } \\
{[20]}\end{array}$ & 2020 & USA & $\begin{array}{l}\text { Retrospective, single- } \\
\text { center }\end{array}$ & 5,549 & 64 & 60 & 1,993 \\
\hline Pei et al. [21] & 2020 & China & $\begin{array}{l}\text { Retrospective, single- } \\
\text { center }\end{array}$ & 333 & 57.1 & 57.1 & 22 \\
\hline $\begin{array}{l}\text { Rubin et al. } \\
\text { [22] }\end{array}$ & 2020 & France & $\begin{array}{l}\text { Retrospective, single- } \\
\text { center }\end{array}$ & 71 & 61.2 & 77 & 57 \\
\hline $\begin{array}{l}\text { Wang et al. } \\
\text { [23] }\end{array}$ & 2020 & China & $\begin{array}{l}\text { Retrospective, } \\
\text { multicenter }\end{array}$ & 138 & 54.3 & 57 & 5 \\
\hline $\begin{array}{l}\text { Zhang et al. } \\
\text { [3] }\end{array}$ & 2020 & China & $\begin{array}{l}\text { Retrospective, single- } \\
\text { center }\end{array}$ & 663 & 55.6 & 48.4 & 68 \\
\hline $\begin{array}{l}\text { Zhou et al. } \\
\text { [2] }\end{array}$ & 2020 & China & $\begin{array}{l}\text { Retrospective, } \\
\text { multicenter }\end{array}$ & 191 & 56 & 62 & 28 \\
\hline
\end{tabular}

\section{TABLE 1: Characteristics of included studies}

AKI: acute kidney injury; COVID-19: coronavirus disease 2019

Statistical analysis 
We finally included 20 studies from various countries. We performed a random effect analysis to find the pooled prevalence, pooled odds ratio (OR) estimates, and 95\% confidence intervals for severe COVID-19 and mortality outcomes in AKI using the 'meta' package by Schwarzer et al. in the R programming language (version 4.16-2), and Cochrane RevMan (version 5.4). The inter-study heterogeneity among the studies was assessed using the $\mathrm{Q}$ statistic proposed by Cochrane and the $\mathrm{I}^{2}$ index introduced by Higgins and Thompson. We interpreted the values greater than $50 \%$ and $70 \%$ to be of moderate and high heterogeneity, respectively. The funnel plot was used to explore the publication bias.

\section{Results}

In our study, a total of 2,771 articles were screened, of which 75 full-length studies were further assessed for eligibility, and 20 articles ultimately met the inclusion criteria. These articles involved 14,415 patients from different countries/regions, including Asia, the USA, and Europe. Most studies were done on hospitalized patients. Due to the small cohort's potential overlapping in many studies, we included only 20 unique articles reporting the association of AKI with the disease severity and mortality in COVID-19 patients. Patients who had high serum creatinine after COVID-19 were deemed to have AKI, as per the diagnostic criteria of Kidney Disease: Improving Global outcomes (KGIDO) guidelines. Patients requiring ICU admission, those having severe dyspnea, lung opacities of $>50 \%$ within one to two days of the disease onset, or oxygen saturation of less than $93 \mathrm{mmHg}$ were considered to have severe COVID-19.

Among the 20 cohorts, the median age was $55.8 \pm 8.39$ years (range: $43-72$ years), and $43.78 \%$ of the patients were female. Out of a total of 14,415 patients, 3,820 developed AKI with a pooled prevalence of $11 \%$ (95\% CI: 0.07-0.15; $\mathrm{p}<0.01 ; \mathrm{I}^{2}=98 \%$ ) (Figure 2).

\begin{tabular}{|c|c|c|c|c|c|c|}
\hline Study & Events & Total & AKI (prevalence) & Proportion & $95 \%-\mathrm{Cl}$ & Weight \\
\hline Cai Q et al.,2020 & 17 & 298 & & 0.06 & {$[0.03 ; 0.09]$} & $5.2 \%$ \\
\hline Cao M et al.,2020 & 10 & 198 & & 0.05 & {$[0.02 ; 0.09]$} & $5.0 \%$ \\
\hline Colaneri M et al.,2020 & 2 & 44 & & 0.05 & {$[0.01 ; 0.15]$} & $3.3 \%$ \\
\hline Feng X et al.,2020 & 35 & 114 & & 0.31 & {$[0.22 ; 0.40]$} & $5.4 \%$ \\
\hline Hu L et al.,2020 & 17 & 323 & & 0.05 & {$[0.03 ; 0.08]$} & $5.2 \%$ \\
\hline Huang C et al.,2020 & 3 & 41 & & 0.07 & {$[0.02 ; 0.20]$} & $3.8 \%$ \\
\hline Regina J etal.,2020 & 30 & 200 & & 0.15 & {$[0.10 ; 0.21]$} & $5.4 \%$ \\
\hline Wan S et al.,2020 & 5 & 135 & & 0.04 & {$[0.01 ; 0.08]$} & $4.4 \%$ \\
\hline Wang D et al.,2020 & 5 & 138 & & 0.04 & {$[0.01 ; 0.08]$} & $4.4 \%$ \\
\hline Yan X et al.,2020 & 10 & 2018 & & 0.00 & {$[0.00 ; 0.01]$} & $5.0 \%$ \\
\hline Zhang G et al.,2020 & 10 & 221 & & 0.05 & {$[0.02 ; 0.08]$} & $5.0 \%$ \\
\hline Zhao XY et al.,2020 & 5 & 91 & & 0.05 & {$[0.02 ; 0.12]$} & $4.4 \%$ \\
\hline Cao J et al.,2020 & 17 & 102 & & 0.17 & {$[0.10 ; 0.25]$} & $5.2 \%$ \\
\hline Brill SE et al.,2020 & 80 & 450 & & 0.18 & {$[0.14 ; 0.22]$} & $5.6 \%$ \\
\hline Chan L et al.,2020 & 1406 & 3235 & + & 0.43 & {$[0.42 ; 0.45]$} & $5.7 \%$ \\
\hline Hirsch JS et al.,2020 & 1993 & 5549 & & 0.36 & {$[0.35 ; 0.37]$} & $5.7 \%$ \\
\hline Pei J et al.,2020 & 22 & 333 & & 0.07 & {$[0.04 ; 0.10]$} & $5.3 \%$ \\
\hline Rubin S et al.,2020 & 57 & 71 & & 0.80 & {$[0.69 ; 0.89]$} & $5.1 \%$ \\
\hline Zhang J et al.,2020 & 68 & 663 & & 0.10 & {$[0.08 ; 0.13]$} & $5.5 \%$ \\
\hline Zhou F et al.,2020 & 28 & 191 & & 0.15 & {$[0.10 ; 0.20]$} & $5.4 \%$ \\
\hline \multirow{3}{*}{$\begin{array}{l}\text { Random effects mode } \\
\text { Heterogeneity: } I^{2}=98 \% \text {, }\end{array}$} & & 14415 & & \multirow{3}{*}{\multicolumn{2}{|c|}{$0.11[0.07 ; 0.15]$}} & $100.0 \%$ \\
\hline & &,$p<0.01$ & & & & \\
\hline & & & 0.6 & & & \\
\hline
\end{tabular}

\section{FIGURE 2: Prevalence of AKI in COVID-19 patients}

AKI: acute kidney injury; COVID-19: coronavirus disease 2019

Twelve studies provided sufficient data in their stated outcomes to measure the association of AKI with the severity of COVID-19. AKI was found to have a significant association with severe COVID-19, with a pooled OR of 8.45 (95\% CI: 5.56-12.86) compared with patients with the nonsevere disease (Figure 3). The results were significant $(\mathrm{p}<0.00001)$, and heterogeneity was negligible $\left(\mathrm{I}^{2}=0 \%\right)$. The funnel plot showing the association between AKI and severe COVID-19 is presented in Figure 4. 


\section{Cureus}

Association of AKI with disease severity in COVID-19 patient

Non-severe

Odds Ratio

Study or Subgroup Events Total Events Total Weight M-H,Random, 95\%

$17.04[5.32,54.65]$ $\mathrm{M}-\mathrm{H}$, Random, $95 \% \mathrm{Cl}$

Cai Q 2020

Cao M 2020

Colaneri M 2020

Feng $\times 2020$

$3 \quad 19$

$\begin{array}{lll}4 & 240 & 13.0 \%\end{array}$

$179 \quad 8.4 \%$

$4.61[1.08,19.57]$
$8.87[0.40,196.82]$

$8.11[2.78,23.71]$

Hu L 2020

$\begin{array}{rrrrr}2 & 17 & 0 & 27 & 1.8 \% \\ 14 & 20 & 21 & 94 & 15.3 \%\end{array}$

$\begin{array}{lllll}15 & 172 & 2 & 151 & 7.9 \%\end{array}$

Huang C 2020

Regina J 2020

$3 \quad 13$

Wan $S 2020$

Wang D 2020

Yan X 2020

Zhang 2020

Zhao XY 2020

$28 \quad 1.9 \%$

$7.12[1.60,31.66]$

$19.00[0.90,399.79]$

$9.81[4.15,23.17]$

$9.81[4.15,23.17]$
$0.58[0.06,5.39]$

$0.58[0.06,5.39]$
$4.55[0.73,28.39]$

$8.25[2.20,30.88]$

$13.96[2.87,67.97]$

$26.53[1.41,497.65]$

Total $(95 \% \mathrm{Cl})$

Total events

90

535

Heterogeneity: $\operatorname{Tau}^{2}=0.00 ; \mathrm{Chi}^{2}=9.50, \mathrm{df}=11(\mathrm{P}=0.58) ; \mathrm{l}^{2}=0 \%$

Test for overall effect: $Z=9.98(P<0.00001)$

$8.45[5.56,12.86]$

$1486 \quad 100.0 \%$

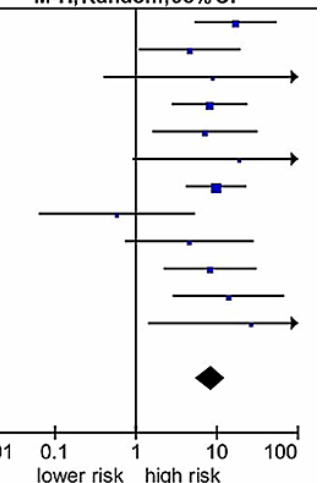

FIGURE 3: Association of AKI with the severity of COVID-19

AKI: acute kidney injury; COVID-19: coronavirus disease 2019

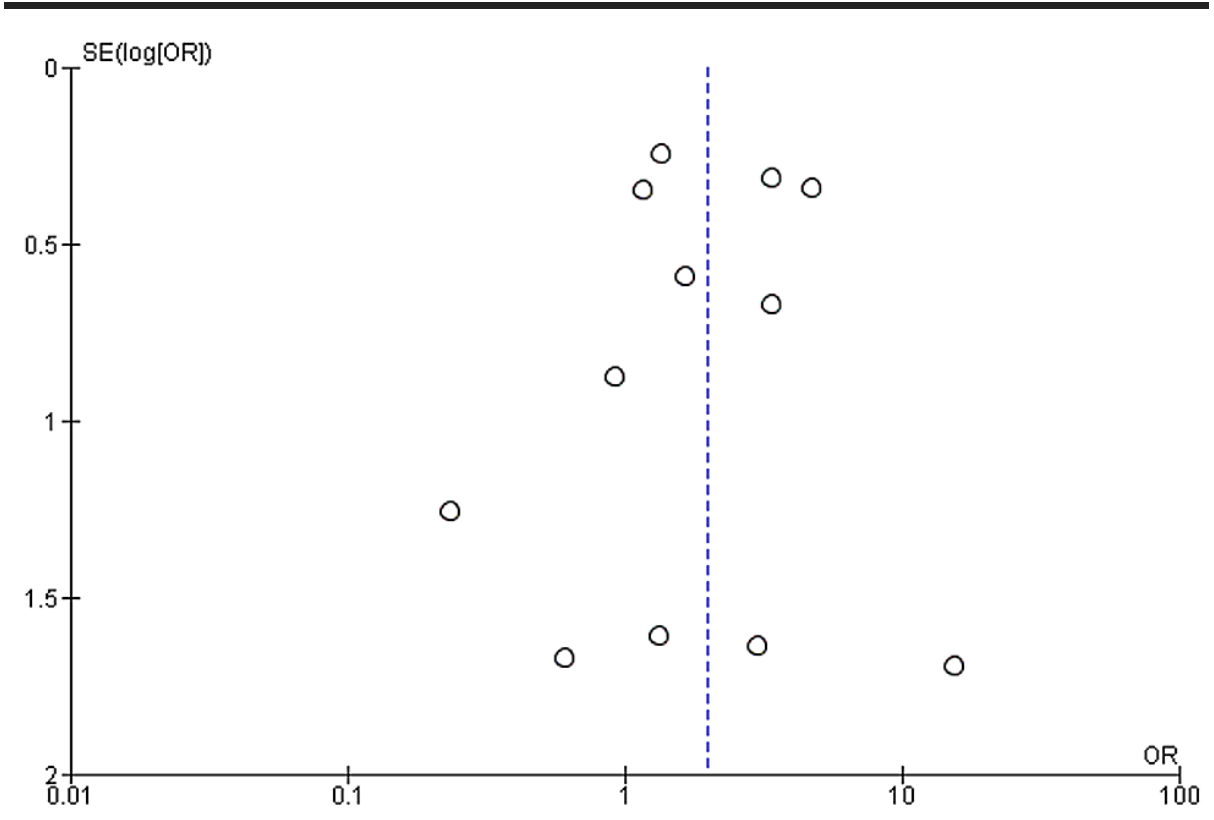

FIGURE 4: Funnel plot analyzing bias in the association between severe COVID-19 and AKI

COVID-19: coronavirus disease 2019; AKI: acute kidney injury

Eight studies provided enough data on mortality in COVID-19 patients with AKI. AKI was associated with significantly higher mortality in patients with COVID-19 with an OR of 13.52 (95\% CI: 5.43-33.67). The results were statistically significant $(\mathrm{p}<0.00001)$, and heterogeneity was high $\left(\mathrm{I}^{2}=88 \%\right)$ (Figure 5$)$. 
Odds ratio of mortality in COVID-19 patients with AKI

\begin{tabular}{|c|c|c|c|c|c|c|c|c|c|c|}
\hline Study or Subgroup & \multicolumn{2}{|l|}{ AKI } & $\begin{array}{r}\text { non- } A \\
\text { Events }\end{array}$ & $\begin{array}{l}\text { AKI } \\
\text { Total } \\
\end{array}$ & Weight & $\begin{array}{c}\text { Odds Ratio } \\
\text { M-H, Random, } 95 \% \mathrm{Cl}\end{array}$ & & \multicolumn{2}{|c|}{$\begin{array}{c}\text { Odds Ratio } \\
\text { M-H,Random, } 95 \% \mathrm{Cl}\end{array}$} & \\
\hline Zhou F 2020 & 27 & 28 & 27 & 163 & $9.8 \%$ & $136.00[17.72,1044.04]$ & & & & $\longrightarrow$ \\
\hline Zhang J 2020 & 5 & 68 & 20 & 595 & $15.5 \%$ & $2.28[0.83,6.29]$ & & & & \\
\hline Wang D 2020 & 0 & 5 & 6 & 133 & $6.2 \%$ & $1.78[0.09,35.83]$ & & & & \\
\hline Rubin S 2020 & 4 & 57 & 0 & 14 & $6.3 \%$ & $2.44[0.12,47.97]$ & & & & \\
\hline Pei J 2020 & 19 & 22 & 10 & 311 & $13.4 \%$ & $190.63[48.39,750.94]$ & & & & $\rightarrow$ \\
\hline Hirsch JS 2020 & 694 & 1993 & 194 & 3456 & $19.1 \%$ & $8.98[7.57,10.67]$ & & & $=$ & \\
\hline Cao J 2020 & 15 & 17 & 5 & 85 & $11.4 \%$ & $120.00[21.27,676.92]$ & & & & \\
\hline Brill SE 2020 & 54 & 85 & 119 & 365 & $18.2 \%$ & $3.60[2.20,5.90]$ & & & $=$ & \\
\hline Total $(95 \% \mathrm{Cl})$ & & 2275 & & 5122 & $100.0 \%$ & $13.52[5.43,33.67]$ & & & & \\
\hline Total events & 818 & & 381 & & & & & & & \\
\hline $\begin{array}{l}\text { Heterogeneity: Tau }{ }^{2} \\
\text { Test for overall effec }\end{array}$ & $\begin{array}{l}1.13 ; \mathrm{Chi}^{2} \\
\mathrm{z}=5.59(\mathrm{~F}\end{array}$ & $\begin{array}{l}=56.21 \\
P<0.00\end{array}$ & $\begin{array}{l}1, \mathrm{df}=7 \\
0001)\end{array}$ & $(P<0.0$ & $00001) ;\left.\right|^{2}$ & $=88 \%$ & 0.01 & $\begin{array}{l}0.1 \\
\text { lower risk }\end{array}$ & $\begin{array}{lr}1 & 10 \\
& \\
& \text { higher risk }\end{array}$ & 100 \\
\hline
\end{tabular}

FIGURE 5: Association between AKI and mortality in COVID-19 patients

AKI: acute kidney injury; COVID-19: coronavirus disease 2019

\section{Discussion}

Although respiratory system involvement is the most prevalent feature of SARS-CoV-2, the infection is generally mild; however, severe infection can lead to severe pneumonia, acute respiratory distress syndrome (ARDS), and multi-organ dysfunction, including that affecting the kidneys. Kidney dysfunction is generally mild; however, it is significantly worse in patients with pneumonia. Generally, kidney dysfunction is characterized by hematuria, proteinuria, and elevated serum creatinine and blood urea nitrogen (BUN) levels. BUN and serum creatinine levels, being significant AKI indicators, have been reportedly higher in patients with nonsevere COVID-19 than in patients with pneumonia [5]. This analysis provides evidence of COVID-19 prevalence and association of AKI with the severity and mortality in COVID-19 patients. Our study reported a more potent association between AKI and severe COVID-19 with a pooled prevalence of 11\% (95\% CI: 0.07-0.15; $\mathrm{p}<0.01 ; \mathrm{I}^{2}=98 \%$ ). AKI had a strong connection with severe SARS-CoV-2, with a pooled OR of 8.45 (95\% CI: 5.56-12.86) compared with those with the nonsevere disease. The results were significant $(\mathrm{p}<0.00001)$, and heterogeneity was negligible $\left(\mathrm{I}^{2}=0 \%\right)$. Regarding the prognosis of COVID-19 patients, AKI was associated with significantly higher mortality with an OR of 13.52 (95\% CI: 5.43-33.67; p<0.00001; $\mathrm{I}^{2}=88 \%$ ). Patients with COVID-19 coupled with AKI have a poor prognosis, and it serves as an independent risk factor for all-cause in-hospital deaths in COVID-19 patients.

Since the emergence of the COVID-19 pandemic, several studies have reported on the prevalence, severity, and prognosis of COVID-19 combined with AKI. A recent study reported a 3\% incidence of AKI in hospitalized patients, and this incidence rate increased to $19 \%$ when patients with severe disease were included [24]. Moreover, Potere et al. have revealed that the prevalence of AKI was reported to be $6 \%$ in hospitalized patients [25]. Lim et al. have reported increased disease severity and mortality in patients with AKI, and the need for ICU care in COVID-19 patients with AKI [26]. Furthermore, in a study by Ali et al., severe AKI was associated with high mortality (relative risk: 3.08; 95\% CI: 1.54-6.19) [27]. AKI in COVID-19 is measured as a key marker of severity and has a negative impact on patient survival [2]. We cannot estimate the real burden of AKI in COVID-19 because the serum creatinine value might not reflect the valid preadmission values, and previous serum creatinine values might not be available at that time [21].

Many recent studies have revealed that AKI has a remarkable prevalence in COVID-19 patients, especially those in ICU. The confirmed proportion of AKI in COVID-19 is variable; however, as per the available data, AKI has a prevalence of more than $20 \%$ in hospitalized patients and more than $50 \%$ in ICU patients $[2,17,20,21]$. A recent study by Wang et al. reported a significant association between AKI and severe COVID19 (OR: 11.88; 95\% CI: 9.29-15.19) and also reported high mortality in COVID-19 patients (OR: 30.46; 95\% CI: 18.33-50-59) [28]. Our study also observed a similar trend, revealing a higher association between AKI and severe SARC-CoV-2 infection ( $\mathrm{p}<0.00001)$ and increased mortality in AKI patients $(\mathrm{p}<0.00001)$. Early detection of AKI and appropriate therapeutic measures are essential to limit morbidity and mortality.

The pathophysiology of AKI in COVID-19 patients is yet to be determined. Several mechanisms have been proposed, including chronic medical conditions such as arterial hypertension, chronic kidney disease, diabetes mellitus, hypovolemic conditions, contrast media, and nephrotoxic drugs. Angiotensin-converting enzyme 2 (ACE2) receptors are the key mediator of viral entry and replication in the host cell. These receptors in multiple organs enable the involvement of different systems, including kidneys and respiratory, nervous, and gastrointestinal systems. In kidneys, ACE2 receptors are expressed in podocytes and apical brush borders of proximal convoluted tubules. ACE2 receptors mediate the viral attachment and entry into the kidney and are responsible for replicating SARS-CoV-2 in the host cells [29]. SARS-CoV-2 also induces an imbalanced activation of the renin-angiotensin-aldosterone system (RAAS), resulting in the downregulation of ACE2 receptors, thereby leading to an increase in angiotensin II. Unprovoked RAAS activation results in a 
cytokine storm, inflammation, arterial constriction, and fibrosis, and thrombosis at the nephron level [5,24]. Gabarre et al. have proposed that cytopathic activity, cytokine storm, hypoperfusion, and microvascular and intravascular coagulation lead to AKI development in COVID-19 patients [30]. The patients with severe COVID-19 have a high level of inflammatory cytokines, leading to the development of AKI.

Our study has several limitations. We have not included any randomized clinical trials, and all the studies were retrospective or prospective in nature. The individual patient data from each article could not be assessed; thus, we could not make our adjustments. Another limitation is the presence of publication bias, as negative studies were less likely to be published. Also, data on COVID-19 patients is rapidly growing, and many cohorts had a comparatively short follow-up duration and presence of limitations in their detailed description. Moreover, this rapidly emerging data make the retrieval of complete evidence on the subject difficult. We have not included the preprint of the studies, as well as abstracts.

AKI after COVID-19 has a significant impact on disease severity and mortality. Our study reported a steady association between AKI and unfavorable outcomes, such as mortality. Given the extent of AKI's impact on COVID-19, emerging literature must provide more comprehensive data on the extent and severity of kidney injury to allow for a proper understanding of the disease prognosis and a comprehensive, resourceful strategy to be adopted during this pandemic.

\section{Conclusions}

There is a growing body of evidence to show that AKI develops in a considerable number of COVID-19 patients, and the condition is significantly associated with adverse outcomes in patients with COVID-19. Thus, it is imperative to exercise extraordinary caution while monitoring the kidney functions of patients regardless of comorbidities and initiating supportive interventions that are surely protective for renal functions in the early stages of SARS-CoV-2 infection. We believe this study will contribute to the physician's essential preparation, which is of utmost significance to managing kidney injury. The only possible way to limit the succeeding AKI in COVID-19 and further progression to more severe stages is to recognize the kidney involvement in COVID-19 at early stages and use preventive and therapeutic measures to reduce morbidity and mortality. Further high-quality data from studies to explore the potential mechanism of the association of AKI with COVID-19 and the underlying cause of mortality are warranted.

\section{Appendices}




\section{Cureus}

\begin{tabular}{|c|c|c|c|}
\hline Author & Reviewer 1 & Reviewer 2 & Reviewer 3 \\
\hline Cai et al. [7] & 2 & 3 & 2 \\
\hline Cao et al. [8] & 3 & 3 & N/A \\
\hline Colaneri et al. [9] & 3 & 3 & N/A \\
\hline Feng et al. [10] & 3 & 3 & $\mathrm{~N} / \mathrm{A}$ \\
\hline Hu et al. [11] & 3 & 3 & N/A \\
\hline Huang et al. [12] & 3 & 2 & 2 \\
\hline Regina et al. [13] & 3 & 3 & N/A \\
\hline Wan et al. [14] & 3 & 3 & N/A \\
\hline Yan et al. [1] & 3 & 3 & N/A \\
\hline Zhang et al. [15] & 3 & 3 & N/A \\
\hline Zhao et al. [16] & 3 & 2 & 3 \\
\hline Cao et al. [17] & 3 & 3 & N/A \\
\hline Brill et al. [18] & 2 & 2 & N/A \\
\hline Chan et al. [19] & 3 & 3 & N/A \\
\hline Hirsch et al. [20] & 3 & 3 & N/A \\
\hline Pei et al. [21] & 3 & 3 & N/A \\
\hline Rubin et al. [22] & 3 & 3 & N/A \\
\hline Wang et al. [23] & 3 & 3 & N/A \\
\hline Zhang et al. [3] & 2 & 3 & 2 \\
\hline Zhou et al. [2] & 3 & 3 & N/A \\
\hline
\end{tabular}

\section{TABLE 2: Risk of bias for included studies}

Risk of bias assessment: each article was given a rating (low=1, medium=2, high=3) according to the NOS. Discrepancies were resolved by a third reviewer if necessary

NOS: Newcastle-Ottawa Scale

\section{Additional Information \\ Disclosures}

Human subjects: Consent was obtained or waived by all participants in this study. Animal subjects: All authors have confirmed that this study did not involve animal subjects or tissue. Conflicts of interest: In compliance with the ICMJE uniform disclosure form, all authors declare the following: Payment/services info: All authors have declared that no financial support was received from any organization for the submitted work. Financial relationships: All authors have declared that they have no financial relationships at present or within the previous three years with any organizations that might have an interest in the submitted work. Other relationships: All authors have declared that there are no other relationships or activities that could appear to have influenced the submitted work.

\section{References}

1. Yan X, Han X, Peng D, et al.: Clinical characteristics and prognosis of 218 patients with COVID-19: a retrospective study based on clinical classification. Front Med (Lausanne). 2020, 7:485. 10.3389/fmed.2020.00485

2. Zhou F, Yu T, Du R, et al.: Clinical course and risk factors for mortality of adult inpatients with COVID-19 in Wuhan, China: a retrospective cohort study. Lancet. 2020, 395:1054-1062. 10.1016/S01406736(20)30566-3

3. Zhang J, Wang X, Jia X, et al.: Risk factors for disease severity, unimprovement, and mortality in COVID-19 patients in Wuhan, China. Clin Microbiol Infect. 2020, 26:767-772. 10.1016/j.cmi.2020.04.012 
4. Naicker S, Yang CW, Hwang SJ, Liu BC, Chen JH, Jha V: The novel coronavirus 2019 epidemic and kidneys . Kidney Int. 2020, 97:824-828. 10.1016/j.kint.2020.03.001

5. Chu KH, Tsang WK, Tang CS, et al.: Acute renal impairment in coronavirus-associated severe acute respiratory syndrome. Kidney Int. 2005, 67:698-705. 10.1111/j.1523-1755.2005.67130.x

6. Yalameha B, Roshan B, Bhaskar LV, Mohmoodnia L: Perspectives on the relationship of renal disease and coronavirus disease 2019. J Nephropharmacol. 2020, 9:22. 10.34172/npj.2020.22

7. Cai Q, Huang D, Ou P, et al.: COVID-19 in a designated infectious diseases hospital outside Hubei Province, China. Allergy. 2020, 75:1742-1752. 10.1111/all.14309

8. Cao M, Zhang D, Wang Y, et al.: Clinical features of patients infected with the 2019 novel coronavirus (COVID-19) in Shanghai, China [PREPRINT]. medRxiv. 2020, 10.1101/2020.03.04.20030395

9. Colaneri M, Sacchi P, Zuccaro V, et al.: Clinical characteristics of coronavirus disease (COVID-19) early findings from a teaching hospital in Pavia, North Italy, 21 to 28 February 2020. Euro Surveill. 2020, 25:2000460. 10.2807/1560-7917.ES.2020.25.16.2000460

10. Feng X, Li P, Ma L, et al.: Clinical characteristics and short-term outcomes of severe patients with COVID19 in Wuhan, China. Front Med (Lausanne). 2020, 7:491. 10.3389/fmed.2020.00491

11. Hu L, Chen S, Fu Y, et al.: Risk factors associated with clinical outcomes in 323 coronavirus disease 2019 (COVID-19) hospitalized patients in Wuhan, China. Clin Infect Dis. 2020, 71:2089-2098. 10.1093/cid/ciaa539

12. Huang C, Wang Y, Li X, et al.: Clinical features of patients infected with 2019 novel coronavirus in Wuhan, China. Lancet. 2020, 395:497-506. 10.1016/S0140-6736(20)30183-5

13. Regina J, Papadimitriou-Olivgeris M, Burger R, et al.: Epidemiology, risk factors and clinical course of SARSCoV-2 infected patients in a Swiss university hospital: an observational retrospective study. PLoS One. 2020, 15:e0240781. 10.1371/journal.pone.0240781

14. Wan S, Xiang Y, Fang W, et al.: Clinical features and treatment of COVID-19 patients in northeast Chongqing. J Med Virol. 2020, 92:797-806. 10.1002/jmv.25783

15. Zhang G, Hu C, Luo L, et al.: Clinical features and short-term outcomes of 221 patients with COVID-19 in Wuhan, China. J Clin Virol. 2020, 127:104364. 10.1016/j.jcv.2020.104364

16. Zhao XY, Xu XX, Yin HS, et al.: Clinical characteristics of patients with 2019 coronavirus disease in a nonWuhan area of Hubei Province, China: a retrospective study. BMC Infect Dis. 2020, 20:311. 10.1186/s12879020-05010-W

17. Cao J, Tu WJ, Cheng W, Yu L, Liu YK, Hu X, Liu Q: Clinical features and short-term outcomes of 102 patients with coronavirus disease 2019 in Wuhan, China. Clin Infect Dis. 2020, 71:748-755. 10.1093/cid/ciaa243

18. Brill SE, Jarvis HC, Ozcan E, et al.: COVID-19: a retrospective cohort study with focus on the over-80s and hospital-onset disease. BMC Med. 2020, 18:194. 10.1186/s12916-020-01665-Z

19. Chan L, Chaudhary K, Saha A, et al.: AKI in hospitalized patients with COVID-19. J Am Soc Nephrol. 2021, 32:151-160. 10.1681/ASN.2020050615

20. Hirsch JS, Ng JH, Ross DW, et al.: Acute kidney injury in patients hospitalized with COVID-19 . Kidney Int. 2020, 98:209-218. 10.1016/j.kint.2020.05.006

21. Pei G, Zhang Z, Peng J, et al.: Renal involvement and early prognosis in patients with COVID-19 pneumonia . J Am Soc Nephrol. 2020, 31:1157-1165. 10.1681/ASN.2020030276

22. Rubin S, Orieux A, Prevel R, et al.: Characterization of acute kidney injury in critically ill patients with severe coronavirus disease 2019. Clin Kidney J. 2020, 13:354-361. 10.1093/ckj/sfaa099

23. Wang D, Hu B, Hu C, et al.: Clinical characteristics of 138 hospitalized patients With 2019 novel coronavirus-infected pneumonia in Wuhan, China. JAMA. 2020, 323:1061-1069. 10.1001/jama.2020.1585

24. Ng JJ, Luo Y, Phua K, Choong AMTL: Acute kidney injury in hospitalized patients with coronavirus disease 2019 (COVID-19): a meta-analysis. J Infect. 2020, 81:647-679. 10.1016/j.jinf.2020.05.009

25. Potere N, Valeriani E, Candeloro M: Acute complications and mortality in hospitalized patients with coronavirus disease 2019: a systematic review and meta-analysis. Crit Care. 2020, 24:389. 10.1186/s13054020-03022-1

26. Lim MA, Pranata R, Huang I, Yonas E, Soeroto AY, Supriyadi R: Multiorgan failure with emphasis on acute kidney injury and severity of COVID-19: systematic review and meta-analysis. Can J Kidney Health Dis. 2020, 7:2054358120938573. 10.1177/2054358120938573

27. Ali H, Daoud A, Mohamed MM, et al.: Survival rate in acute kidney injury superimposed COVID-19 patients: a systematic review and meta-analysis. Ren Fail. 2020, 42:393-397. 10.1080/0886022X.2020.1756323

28. Wang B, Luo Q, Zhang W, et al.: The involvement of chronic kidney disease and acute kidney injury in disease severity and mortality in patients with COVID-19: a meta-analysis. Kidney Blood Press Res. 2021, 46:17-30. 10.1159/000512211

29. Hoffmann M, Kleine-Weber H, Schroeder S, et al.: SARS-CoV-2 cell entry depends on ACE2 and TMPRSS2 and is blocked by a clinically proven protease inhibitor. Cell. 2020, 181:271-280. 10.1016/j.cell.2020.02.052

30. Gabarre P, Dumas G, Dupont T, Darmon M, Azoulay E, Zafrani L: Acute kidney injury in critically ill patients with COVID-19. Intensive Care Med. 2020, 46:1339-1348. 10.1007/s00134-020-06153-9 